Uluslararası Sosyal Bilgilerde Yeni Yaklaşımlar Dergisi, 2021, 5(1), 278-293

International Journal of New Approaches in Social Studies, 2021, 5(1), 278-293

\title{
Beliren Yetişkinlik Dönemindeki Bireylerin Kişilik Özelliklerinin İncelenmesi*
}

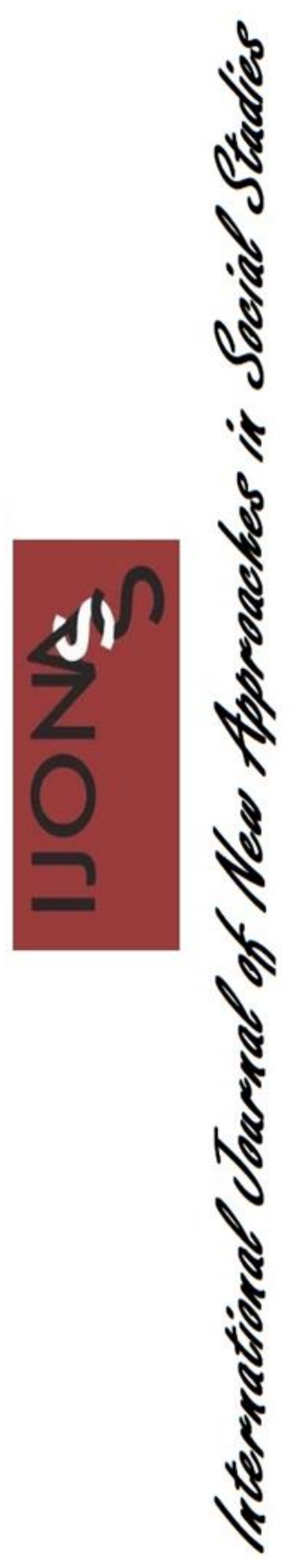

\author{
Musa EROĞLU ${ }^{1 * *}$ (1) \& Mehmet GÜNDOĞDU²
}

Gönderilme Tarihi: 10 Mayıs 2021

Kabul Tarihi: 16 Haziran 2021

DOI: $10.38015 /$ sbyy. 946518

\begin{abstract}
Öz:
Gelişim bir bütün olarak incelendiğinde ergenlik ve yetişkinlik arasında geçen süre bireyin yetişkin olarak nitelenebilmesi için oldukça önemlidir. Bu durumda yetişkinlik süreci ergenlik dönemi ile başlamakta ve bireyin kendini yetişkin olarak görmesiyle son bulmaktadır. Fakat sadece bireyin kendini yetişkin olarak hissetmesi yetmez. Bireyin ailesi ve çevresi hatta daha geniş bir çerçeveden bakıldığında içinde yaşadiğı toplum ve ülkede geçerli olan kanunlarında bireyi yetişkin olarak görmesi gerekir. Bireysel ve çevresel süreçler beraber değerlendirildiğinde; bireylerin sorumluluklarl, toplumda ve ailede tanınan ayrıcalıklar bireylerin yetişkin olup olmamalarını değerlendirmeleri de önemlidir. Beliren yetişkinlik dönemi de bütün gelişimsel dönemler gibi kendine has özelliklere sahiptir. Bu araştırmanın amacı beliren yetişkinlik dönemindeki bireylerin kişilik özelliklerini incelemektir. Araştırmanın örneklemini 18-30 yaş aralı̆̆ındaki Mersin Üniversitesi öğrenci ve çalışanları, Mersin Şehir Hastanesi çalışanları ve 4 ayrı özel kurs ögrencileri olmak üzere toplam 750 birey oluşturmaktadır. Katılımcılara demografik bilgi anketi, Yaşam Görüşü Ölçeği, Genişletilmiş Sıfatlara Dayalı Kişilik Testi uygulanmıştır. Araştırma bulguluranıa göre beliren yetişkinlik döneminin 30 yaş hatta üzeri olabileceği düşünülmektedir. Kişilik özellikleri bakımından araştırma bulgularına göre beliren yetişkinlik dönemindeki bireylerin dışa dönük kişilik özelliğine sahip olabilecekleri, bununla birlikte beliren yetişkinlik dönemindeki bireylerin deneyime açık kişilik özelliğine de sahip olabilecekleri ön görülmektedir.
\end{abstract}

Anahtar Kelimeler: Beliren yetişkinlik, kişilik, kişilik özellikleri.

\begin{abstract}
:
When development is examined as a whole, the period between adolescence and adulthood is very important for an individual to be qualified as an adult. In this case, the adulthood process begins with adolescence and ends when the individual sees himself as an adult. But it is not enough for the individual to feel himself as an adult alone. The individual's family and environment, and even from a wider perspective, should see the individual as an adult in the laws that are valid in the society and country in which he lives. When individual and environmental processes are evaluated together; It is also important for individuals to evaluate the responsibilities of individuals, the privileges granted in society and the family, whether they are adults or not. Emerging adulthood, like all developmental periods, has its own characteristics. The aim of this research is to examine the personality traits of individuals in emerging adulthood. The sample of the study consists of a total of 750 individuals, including Mersin University students and staff aged 18-30, employees of Mersin City Hospital and students of 4
\end{abstract}

\footnotetext{
${ }^{1}$ Mersin Üniversitesi, Türkiye, ORCID ID: 0000-0001-7588-6385

${ }^{2}$ Mersin Üniversitesi, Türkiye, ORCID ID: 0000-0002-9309-6974

*Bu makale 31.01.2020 tarihinde Maltepe Üniversitesi Lisanüstü Eğitim Enstitüsü’nde Kabul edilmiş olan Beliren Yetişkinlik Dönemindeki Bireylerin Bağlanma Stillleri. Kimlik Statüleri ve Kişilik Özelliklerinin İncelenmesi adlı doktora tezinden türetilmiștir.

*** SorumluYazar (Corresponding Author): eroglumusa33@ gmail.com
} 
developed by Chambers (1983) were used. As research findings, social studies teacher candidates were found to form a total of 227 different metaphors under seven different categories: Method, characteristics of the nature of science, and misconceptions for the concept of "scientific research" personal characteristics, occupational characteristics, occupational environment and tools used, and model scientist for the concept of "scientist". According to the results of the study, the perceptions of the teacher candidates on the concept of scientific research were methods, characteristics of the nature of science, and errors. Teacher candidates have some misconceptions about the nature of science. Within the scope of teacher training aimed at eliminating the teacher candidates' misconceptions about scientific research, the courses aimed at effectively teaching scientific research, the processes of science, and the nature of science should be included in the curriculum. Their perceptions of the scientist concept were determined to be personal characteristics, occupational characteristics, occupational environment, and tools they use. Teacher candidates perceive the characteristics of scientists as individuals who conduct experiments, work in laboratories, question, solve problems, and guide society.

Keywords: Scientific literacy, scientific research, scientist, metaphorical perception.

\section{GíRiş}

Yetişkin olmak çağdaş toplumlarda gittikçe karmaşık bir yapı haline gelen ve çeşitlenen bir süreçtir. Yetişkin olmanın yaşı ve ölçütleri 21. yüzyılda sürekli değişime uğramaktadır. Bilimsel çalışmalar birçok farklı kuramlarla yetişkinliğin ne olduğunu ve yetişkinliğe geçişin nasıl olduğunu açıklamışlardır. Bunların içinde beliren yetişkinlik farklı bir yaşam dönemi önerisiyle yeni bir yaklaşım olarak ortaya çıkmıştır (Atak \& di ğ., 2016). Ergenlik ile genç yetişkinlik arasındaki dönem beliren yetişkinlik dönemi olarak tanımlanmaktadır. Arnett (2000; 2004). Erikson' un, Keniston' un ve Levinson 'un gelişim ile ilgili yaklaşımlarını esas alarak 18 - 25 yaş aralığındaki döneme beliren yetişkinlik dönemi adını vermiştir (Atak, 2005). Beliren yetişkinlik (emerging adulthood) evresi ergenlik dönemi ile yetişkinlik arasında bir evre olarak tanımlanabilir (Morsünbül, 2013). Beliren yetişkinlik dönemindeki bireyler, ergenliği tamamlamış ama tam bir yetişkinlik statüsü kazanamamış bireylerdir. Bu dönemdeki bireyler, tam bir yetişkin olabilmek için ve içinde yaşadıkları kültürce belirlenen yetişkinlik gereklerini karşılamak için gereken becerileri, kapasiteleri ve karakter özelliklerini kazanmaktadırlar (Arnett, 1998). Gelişim bir bütün olarak incelendiğinde ergenlik ve yetişkinlik arasında geçen süre bireyin yetişkin olarak nitelenebilmesi için oldukça önemlidir. Bu durumda yetişkinlik süreci ergenlik dönemi ile başlamakta ve bireyin kendini yetişkin olarak görmesiyle son bulmaktadır. Fakat sadece bireyin kendini yetişkin olarak hissetmesi yetmez. Bireyin ailesi ve çevresi hatta daha geniş bir çerçeveden bakıldığında içinde yaşadığı toplum ve ülkede geçerli olan kanunlarında bireyi yetişkin olarak görmesi gerekir. Bireysel ve çevresel süreçler beraber değerlendirildiğinde; bireylerin sorumlulukları, toplumda ve ailede tanınan ayrıcalıklar bireylerin yetişkin olup olmamalarını değerlendirmeleri de önemlidir (Bacanlı \& Terzi, 2015). Kültürel farklar yetişkinliğin belirlenmesinde farklı kriterler ve farklı geçiş işaretlerine önem verilmesine sebep olabilir (Arnett, 2000). Yetişkin olmak çağdaş toplumlarda gittikçe karmaşık bir yapı haline gelen ve çeşitlenen bir süreçtir. Yetişkin olmanın yaşı ve ölçütleri günümüzde sürekli değişime uğramaktadır. Bilimsel çalışmalar birçok farklı kuramlarla yetişkinliğin ne olduğunu ve yetişkinliğe geçişin nasıl olduğunu açıklamışlardır. Bunların içinde beliren yetişkinlik farklı bir yaşam dönemi önerisiyle yeni bir yaklaşım olarak ortaya çıkmıştır (Atak \& diğ., 2016). Ergenlik ile genç yetişkinlik arasındaki dönem beliren yetişkinlik dönemi olarak tanımlanmaktadır (Arnett, 2000; Arnett, 2004). Erikson' un, Keniston' un ve Levinson'un gelişim ile ilgili yaklaşımlarını esas alarak 18 - 25 yaş aralığındaki döneme beliren yetişkinlik dönemi adını vermiştir. Adı geçen bu dönem sanayileşmiş toplumlardaki birçok birey için büyük bir değişimin yaşandığı çok önemli bir yaşam dönemi olarak kabul edilmektedir. Beliren yetişkinlik dönemindeki bireyler genellikle kendilerini ergen olarak görmemekte fakat tam anlamıla bir yetişkin olduklarını da düşünmemektedirler (Arnett, 2000). Bu dönemde 
demografik değişkenlerle ilgili olarak en fazla değişim evlenme, anne-baba olama ve yükseköğrenime devam etme konularında olmaktadır (Arnett, 2004). Beliren yetişkinlik dönemi de bütün gelişimsel dönemler gibi kendine has özelliklere sahiptir. Arnett'e göre (2004) beliren yetişkinlik döneminin beş temel özelliği vardır. Bu özelliklerin ilki bu dönemin bir kimlik arayışı dönemi olmasıdır. Ergenlik dönemindeki kimlik kazanma çalışmaları kimlik kazanımının ergenlik dönemi ile başladığını fakat ergenlik sonrasında da devam ettiğini göstermektedir. Beliren yetişkinlik dönemindeki bireyeler iş, dünya görüşü ve romantik ilişki konularında kimlik arayışlarını sürdürmektedirler. Beliren yetişkinliğe has bir başka özellik ise bu dönemin bir istikrarsızlık dönemi olmasıdır. Bu dönemde sık sık iş değişiklikleri, romantik bir ilişkiye başlama ve bitirme ve ev değiştirme gibi istikrarsızlıklar görülebilmektedir. $\mathrm{Bu}$ dönemin üçüncü özelliği, bireylerin kendine odaklı olduğu bir dönem olmasıdır. Bu dönemde bireyler kendi kararlarını verme zorunluluğu hissetmekte, kendi kararlarını yaşamakta, yaşama karşı kendilerini hazırlamakta ve kendi ayakları üzerinde durmayı öğrenmektedirler. Bu dönemin diğer bir özelliği sonsuz olanaklar dönemi olmasıdır. Bu dönemdeki bireylerin hayatlarını değiştirebilmek için çok fazla imkanları, beklentileri ve geleceğe dair umutları vardır. Beliren yetişkinlik döneminin beşinci ve son özelliği ise bu dönemdeki bireylerin arada kalmışlık hissi yaşıyor olmalarıdır. Bireyler bu dönemde ergenlik ile yetişkinlik hissi arasında gidip gelmektedirler

Kişilik ise "bireyin kendisinden kaynaklanan tutarlı davranış kalıpları ve kişilik içi süreçler" olarak tanımlanabilir (Burger, 2006). Bir başka tanımda ise "bireyi diğerlerinden ayıran, bireye özgü, tutarlı ve yapılaşmış özellikler bütünü” olarak ifade edilmektedir (İnanç \& Yerlikaya, 2016). Kişilikle ilgili çok sayıda kuram ve görüş vardır, bu kuramlardan biri de Beş Faktör Kuramıdır. McCrea ve Costa 1983-1985 yılları arasında yaptıkları çalışmalar neticesinde kişilikte beş temel boyutun olduğunu keşfetmişlerdir. Başlangıçta sadece kişilik özelliklerinin sınıflaması olan bu beş faktör zaman içinde bir kişilik kuramına dönüşmüştür. Elde edilen tutarlı bulgularla kişiliğin yapısını oluşturan şeyin ne olduğu sorusuna doyurucu bir yanıt bulduklarını düşünen McCrea ve Costa (2003) faktör analizi çalışmaları sonucunda; dişa dönüklük, nevrotizm, deneyime açıklık, uyumluluk ve öz-disiplin olmak üzere beş temel kişilik özelliği olduğunu öne sürmüşlerdir (İnanç \& Yerlikaya, 2016). Kişiliği açıklamak için kişilik kuramcıları farklı kuramsal yapılar öne sürmüşlerdir. Çeşitli kaynaklardan çıkan bu kuramlar, çoğu kez birbiriyle uyumlu bir özellik göstermelerine karşın bazen çelişen özelliklerde göstermişlerdir. Özellikleri tanımlayan sıfatlar; kişiliği tam anlamıyla kapsamasalar da kişiliğin ele alınmasında geniş bir çerçeve sağlamıştır (Somer, 1998). Yapılan araştırmalar sonucunda kişilik özelliklerinin sınıflandırılmasında, beş büyük kişilik özelliği üzerinde bir görüş birliğine varılmıştır. Bu beş büyük kişilik özelliği sayısız doğal dil ve bilimsel özellik kavramını tek bir sınıflandırma çerçevesinde düzenleyen tanımlayıcı bir sınıflama meydana getirmiştir (John \& Srivastava, 1999). McCrea ve Costa'nın (2003) faktör analizi çalışmaları sonucunda keşfettikleri beş temel kişilik özelliği, dişa dönüklük, nevrotizm, yumuşak başl1lık, deneyime açıklık ve öz disiplindir (sorumluluk). Bu boyutlar aşağıda kısaca anlatılmıştır.

\section{Nevrotiklik}

Bu boyut genellikle güvensiz, endişeli, korumacı, gergin ve kaygılı bireyleri işaret etmektedir (Costa \& McCrae, 1992). McCrae ve Costa (1991) kişilik psikologlarının, nevrotizm terimini, ruhsal huzursuzluğu deneyimlemeye yatkınlıkla tanımlanan, normal bir kişilik boyutu olarak gördüklerine işaret etmektedirler. McCrae ve Costa (1987), birçok araştırmacının nevrotizmin temelde depresyon, anksiyete, kızgınlık, sıkıntı gibi olumsuz duyguları kapsadığı yönünde fikir birliği içinde olduklarına işaret etmektedirler. Diğer bazı araştırmacıların da nevrotizmi, rasyonel olmayan düşünceler ve başa çıkma mekanizmalarında yetersizlikle bağlantılı 
gördüklerini ifade etmektedirler. Araştırmacılar, bu boyutta yüksek puan alan kişilerin, daha sıklıkla karmaşık duygularla uğraşmak zorunda olduklarından, daha çok kuruntulu düşünceler ve düşmanca tepkiler gibi uygun olmayan başa çıkma mekanizmalarına başvurduklarını belirtir. Buna göre, bu kişiler, yaşadıkları duygularla uygunluk gösteren, kendini suçlama türünde düşüncelere daha sık kapılmaktadırlar (Seviniş, 2017).

\section{Dışa Dönüklük}

Bu kişilik boyutundaki bireyler, heyecanlı, hayat dolu, neşeli, girişken, sosyal olma konuşkan gibi özelliklere sahiptirler. Dışadönüklük daha çok kişiler arası ilişkilerde sosyal uyaranların miktarı ile ilişkilidir. Bunun yanı sıra, insanlarla birlikte olmayı sevme, sosyallik, eğlenceyi sevme, güç, liderlik, arkadaşça davranma gibi özellikler de bu faktörü temsil etmektedir (Karduz, 2019). Daha yüksek enerji potansiyelleri sayesinde dişadönükler verilen zamanda daha fazla tasarı üretebilir ve içe dönüklere göre daha az yorgunluk hissi duyabilirler. Hatta olayların olumlu taraflarından bakarak daha az stresli hayat sürebilirler. Daha az gergin ve daha az zaman endişesine neden olan olumlu enerjileri sayesinde dişadönükler genelde çatışma yaşamazlar. Araştırmacılara göre dışadönükler daha fazla pozitif etkiye daha fazla pozitif olay beklentisine ve içe dönüklerden daha fazla enerjiye sahiptirler. Bu yüzden etraflarına daha fazla pozitif enerji yayar ve daha fazla olumlu ruh haline sahip olurlar (McCrea \& Costa, 2003).

\section{Yumuşak Başlılık}

Yumuşak başlılıkla ilgili sınıflandırmalar, bir kişinin duygularında, düşüncelerinde ve davranışlarında, şefkatten düşmanlığa uzanan bir çizgi boyunca kişiler arası uyumun niteliğini değerlendirmek için kullanılır. Bu boyutta yüksek puan alan kişiler, yumuşak kalpli, iyi huylu, güvenli, yardımsever, bağışlayıcı, saf ve dürüst olarak tanımlanabilir. Bu boyutta düşük puan alan kişiler ise kötümser, kaba, güvensiz, işbirliğine kapalı, intikamcı, merhametsiz, sinirli ve çıkarcı olarak tanımlanabilir (Costa \& McCrea, 1980). Costa, McCrae ve Dye (1991), yumuşak başlılık boyutunun, aynı dişadönüklük boyutu gibi kişilerarası ilişkilere bağlı bir boyut olduğunu belirtmişler, ancak dişadönüklüğün sosyal uyaranlarının miktarı ile ilişkili olduğunu, yumuşak başlılığın ise ilişkilerin niteliği ile bağlantılı olduğunu vurgulamışlardır. Araştırmacılar, yumuşak başlılığın alt boyutları olarak güven, dürüstlük, elseverlik (alturizm), uyma/itaat, alçak gönüllülük ve merhametliliği tanımlamışlardır. Bu boyutun, kişilerarası ilişkilerde etkili olmasının yanı sıra, kişinin kendilik-algısını etkilediğini, sosyal tutumlar ve yaşam felsefesi geliştirmekte de etkili olduğunu işaret etmişlerdir.

\section{Sorumluluk}

Costa, McCrae ve Dye (1991) sorumluluk faktörünün alt boyutlarını yeterlilik, düzen, görevşinaslık, başarı çabası, öz disiplin ve tedbirlilik olarak tanımlamışlardır. Yeterlilikle kastedilen, ehliyetli, makul ve hünerli olmaktır. Bu noktada, dilden hareketle kişilik özelliklerini inceleyen birçok çalışmada, kişilerin kendilerinde ya da başkalarında tanımladıkları iki boyut olan zeka ile sorumluluğun korelasyon gösterdiğine işaret edilmektedir. Düzen alt boyutu, kişinin çevresini düzenli tutma ve iyi bir şekilde organize olma eğilimini belirtmektedir. Düzen boyutunun patolojik formu, kompulsif davranışlarla kendini göstermektedir. Görevşinaslık, davranış standartlarına katı bir biçimde bağlılıkla ilişkilidir. Yazarlar, Freudyen süper ego-gücü kavramının da bu boyutla bağlantılı olduğuna işaret etmektedirler. Sorumluluk, dikkat dağıtıcı faktörlere ve sıkılmaya rağmen bir göreve devam edebilme yeteneğini ve özellikle sabırlı olmayı yansıtır. Bu özellikte düşük puanı olanların, ertelemeye ve hayal kırıklığı karşısında çabuk pes etmeye eğilim gösterdikleri bildirilmektedir. Bu faktör için önerilen son alt boyut olan tedbirlilik, anlam olarak, ihtiyatlı, planlı ve dikkatli olmayı temsil etmektedir. 


\section{Deneyime Açıklık}

Costa ve McCrae (1992), deneyime açıklık ile ilgili kişilik özelliklerini analitik, karmaşık, liberal, geleneksel olmayan, hayal gücü kuvvetli, ilgileri geniş, cesur, değişikliği seven, merak, özgünlük, fikirlere açıklık ve sanata duyarlılık olarak belirtmiştir. Ayrıca, ölçülen zekânın, hem derecelenen zekâdan hem de gelişime açıklık boyutundan ayrı bir faktör olduğu sonucuna varmışlardır. Burger'e göre (2006) deneyime açıklık boyutu, kişiler arası ilişkilerde açık olmaktan çok, deneyimlere açık olmak anlamındadır. Bu boyutu oluşturan özellikler arasında güçlü bir hayal gücü, yeni görüşleri kabul etme istediği, çok yönlü düşünme ve zihinsel merak vardır. Deneyime açıklık boyutunda yüksek puan alan kişiler, gelenek dışı ve bağımsız düşüncelere sahiptir. Deneyime açıklık boyutundan düşük puan alan kişiler daha gelenekçidir. $\mathrm{Bu}$ kişiler yeni olan şeylerden ziyade bilineni tercih ederler.

\section{Araştırmanın Amacı}

$\mathrm{Bu}$ araştırmanın temel amacı, beliren yetişkinlik dönemindeki bireyler ile beliren yetişkinlik döneminde olmayan bireylerin kişilik özelliklerinin incelenmesidir. Ayrıca çalışmada beliren yetişkinlik döneminin demografik değişkenlere göre farklılaşıp farklılaşmadığını araştırmaktır. Araştırmanın amacına göre aşağıdaki sorulara yanıt aranmıştır.

1. Beliren yetişkinlik dönemindeki bireylerin kişilik özellikleri ile beliren yetişkinlik döneminde olmayan bireylerin kişilik özellikleri arasında anlamlı bir fark var mıdır?

2. Beliren yetişkinlik dönemi ve alt boyutları; cinsiyet, yaş, çalışma durumu ve barınılan yer gibi demografik değişkenlere göre farklılaşmakta mıdır?

\section{Araştırmanın Önemi}

Bu çalışma Türkiye'de beliren yetişkinlik döneminin yaşanması, beliren yetişkinlik dönemine etki eden faktörlerin neler olduğunun anlaşılması konusunda bilgi sunacaktır. Ayrıca beliren yetişkinlik döneminde olan bireylerin kişilik özellikleri incelenmiştir. Literatür taraması yapıldığında konuyla ilgili sınırlı sayıda çalışmaların olduğu görülmektedir. $\mathrm{Bu}$ çalışma demografik özellikler bakımından Türkiye'de beliren yetişkinlik konusunu ele alması, ülkemizde bu dönemin yaşanmasına etki eden faktörleri belirlemesi beliren yetişkinlik döneminde kişilik özelliklerinin belirlenmesi yönünden ve bundan sonra yapılacak çalışmalara da 1şık tutması açısından önemli olacaktır.

\section{YÖNTEM}

\section{Araştırma Modeli}

Beliren yetişkinlik dönemini ve bu dönemdeki kimlik statüleri ile bağlanma stillerinin inceleneceği bu araştırma nicel bir araştırma olup tarama modeli ile yapılacaktır. Tarama modeli, geçmişte ya da halen var olan bir durumu var olduğu biçimiyle betimlemeyi amaçlayan araştırma yaklaşımıdır (Karasar, 2014). Tarama modeliyle gerçekleştirilen araştırmalarda, araştırma konusuyla ilgili davranış, tutum, beklenti, gereksinim ve bilgi düzeylerinin belirlenmesi mümkündür (Neuman, 2000).

\section{Çalışma Grubu}

Bu çalışmanın evrenini, 18-30 yaş aralığındaki; beliren yetişkinlik döneminde olan bireyler ve aynı yaş grubunda beliren yetişkinlik döneminde olmayan 750 birey oluşturmuştur. Ancak bunlardan 48 kişi testlerde bazı soruları boş bıraktıkları ya da bir soruya birden fazla cevap verdikleri için değerlendirmeye alınmamıştır. Uç değerler de atıldığında 673 kişi ile değerlendirme yapılmıştır. Aşağıda örneklemin demografik dağılım tabloları gösterilmiştir. 
Tablo 1. Çalışma Grubuna Ait Cinsiyet Dağılım Tablosu

\begin{tabular}{lcc}
\hline Cinsiyet & Say1 & $\%$ \\
\hline Kadın & 479 & 71,17 \\
Erkek & 194 & 28,83 \\
\hline Toplam & 673 & 100 \\
\hline
\end{tabular}

Tablo 1 de görüldüğü gibi, örneklemde 479 kadın, 194 erkek olmak üzere toplam 673 kişi değerlendirmeye alınmış olup; kadınların oranı $\% 71,17$, erkeklerin oranı $\% 28,83$ tür.

Tablo 2. Çalıșma Grubuna Ait Yaș Dağılım Tablosu

\begin{tabular}{lcc}
\hline Yaş & Say1 & $\%$ \\
\hline $1(18,19,20,21)$ & 266 & 39,5 \\
$2(22,23,24,25)$ & 298 & 44,3 \\
$3(26,27,28,29,30)$ & 109 & 16,2 \\
\hline Toplam & 673 & 100 \\
\hline
\end{tabular}

Tablo 2 de görüldüğü gibi, örneklemde 18-21 yaş aralığında266 kişi, 22-25 yaş aralığında 298 kişi, 26-30 yaş aralığında 109 olmak üzere 673 kişi değerlendirmeye alınmış olup; 18-21 yaş aralığının oranı 39,5, 22-25 yaş aralığını oranı 44,3, 26-30 yaş aralığının oranı 16,2 dir.

Tablo 3. Çalışma Grubuna Ait Barınılan Yer Dağılım Tablosu

\begin{tabular}{lcc}
\hline Kaldığı Yer & Say1 & $\%$ \\
\hline Aile Yanında & 347 & 51,56 \\
Akraba Yanında & 25 & 3,71 \\
Arkadaşla Evde & 66 & 9,80 \\
Yalnız & 27 & 4,01 \\
Devlet Veya Özel Yurt & 187 & 27,78 \\
Diğer & 21 & 3,12 \\
\hline Toplam & 673 & 100 \\
\hline
\end{tabular}

Tablo 3 te görüldüğü gibi, örneklemde ailesi ile kalanların sayısı 347, bir akrabasının yanında kalanların sayısı 25, arkadaşıyla evde kalanların sayısı 66 , yalnız yaşayanların sayısı 27 , devlet yurdu veya özel yurtta kalanların sayısı 187, diğer barınma yerlerinde kalanların sayısı 21 olmak üzere toplam 673 kişi değerlendirmeye alınmıştır. Ailesiyle yaşayanların oranı $\% 51,56$, bir akrabasının yanında kalanların oranı $\% 3,71$, arkadaşıyla evde kalanların oranı $\% 9,8$, yalnız yaşayanların oranı \% 4,01, devlet yurdu veya özel yurtta kalanların oranı 27,8 diğer barınma yerlerinde kalanların oran 1 ise $\% 3,12$ dir.

Tablo 4. Çalışma Grubuna Ait Çalışma Durumu Dağılım Tablosu

\begin{tabular}{lcc}
\hline Çalışma Durumu & Say1 & $\%$ \\
\hline Çalışıyor & 34 & 5,05 \\
Çalışmıyor & 122 & 18,13 \\
Öğrenci & 441 & 65,52 \\
Çalışıyor Ve Öğrenci & 76 & 11,30 \\
\hline Toplam & 673 & 100 \\
\hline
\end{tabular}

Örneklemde çalışanların sayısı 34, çalışmayanların sayısı 122, öğrencilerin sayısı 441, hem çalışıp hem öğrenci olanların sayısı 76 olmak üzere toplam 673 kişi değerlendirmeye alınmış olup; çalışanların oranı $\% 34$, çalışmayanların oranı $\% 18,13$, öğrencilerin oranı $\% 65,52$, hem çalışıp hem öğrenci olanların oranı ise $\% 11,30$ dur. 


\section{Veri toplama araçlart}

Kişisel Bilgi Formu: Katılımcıların yaş, cinsiyet ve eğitim durumları, ekonomik durumları, barındıkları yer gibi demografik özelliklerine ait bilgiler kişisel bilgi formu vasıtasıyla elde edilmiştir.

Yaşam Görüşü Ölçeği: Arnett, Reiffman ve Colwell (2003) tarafından geliştirilmiş olan "Yaşam Görüşü Ölçeği', adlı ölçek kullanılmıştır. Geçerlik, güvenirlik ve faktör analizi çalışmaları yapılan ölçeğin Türkçe'ye uyarlanmış hali kullanılmıştır. Ölçeğin orijinal hali 31 maddeden oluşan 4 dereceli likert tipi bir ölçektir. Ölçek, "Deneme-yanılma, Kimlik keşfi, Olumsuzluk-kararsızlık, Kendine odaklanma, Başkalarına odaklanma ve Arada hissetme" alt faktörlerden oluşmaktadır. Bu alt ölçeklerden "Kimlik keşfi, Deneme-yanılma, Olumsuzlukkararsızlık, Kendine odaklanma ve Arada hissetme" ölçekleri beliren yetişkinlik kuramıyla ve beliren yetişkinlik döneminin özellikleriyle uyumlu, "Başkalarına odaklanma" alt faktörü ise beliren yetişkinlik kuramına ve bu dönemin özelliklerine ters olan maddeleri içermektedir. Türkçe'ye uyarlanma süreci içinde yapılan faktör analizinde "Başkalarına odaklanma" alt ölçeğine ait maddeler madde yük değerleri düşük olduğu için ölçekten çıkarılmıştır (Atak \& Çok, 2008). Temel Bileşenler Analizi sonunda ölçeğin 3 faktörlü bir yapıda olduğu ve açıkladığı toplam varyansın 44,81 olduğu bulunmuştur. Analiz sonucunda, birinci faktör, beliren yetişkinlik döneminin "kararsızlık, değişkenlik ve olumsuzluk" gibi özelliklerine ilişkin maddeleri içerdiği için "Olumsuzluk/Kararsızlık (M2, M3, M4, M5, M6, M10, M12)”, ikinci faktör beliren yetişkinlik döneminin kim olduğunu bulma ve kendini bir geçiş döneminde hissetme gibi özelliklerine ilişkin maddeleri içerdiğ için "Kimlik keşfi/Arada hissetme (M7, M16, M17, M18, M19, M20)" olarak adlandırılmıştır. Üçüncü faktör ise, beliren yetişkinlik döneminde bireyin kendine ve kendi yaşamına odaklanma, yeni şeyleri fark etme, deneme ve keşfetme gibi temel özelliklerine ilişkin maddeleri içermektedir; "Deneme/Kendine odaklanma (M1, M8, M9, M11, M13, M14, M15)". Ölçekten alınacak en düşük puan 20, en yüksek puan ise $80^{\prime}$ dir. Yapılan faktör analizi sonunda, 20 maddelik ölçekte 3. maddenin tersten yorumlanması gerektiği ortaya çıkmıştır. Ölçeğin cronbach alpha iç tutarlılık katsayısı $\alpha=, 69$ bulunmuştur. Test tekrar test güvenirlik kat sayısı ise ,81 bulunmuştur (Atak ve Çok, 2008). Bu çalışmada ölçeğin cronbach alpha iç tutarlılık katsayısı $\alpha=, 76$ bulunmuştur.

Sıfatlara Dayalı Kişilik Testi (SDKT): Bacanlı, İlhan ve Aslan (2007) tarafından geliştirilen test Costa ve McCrea' nın Beş Faktör Kişilik kuramına dayanmaktadır. Duygusal Dengesizlik, Dışadönüklük, Deneyime Açıklık, Yumuşak Başlılık ve Sorumluluk alt boyutlarını kapsayan 40 sorudan oluşmaktadır. SDKT'nin boyutlarının iç tutarlık katsayılarının .73 ile .89 aralığı arasında değiştiği görülmektedir. Test tekrarına ilişkin bulgularda en yüksek ilişkiyi Yumuşak Başlılık $(\mathrm{r}=.86, \mathrm{p}<.01)$, en düşük ilişkiyi ise Deneyime Açıklık boyutunun $(\mathrm{r}=.68, \mathrm{p}<.01)$ ortaya koyduğu belirtilmektedir (Bacanlı, İlhan \& Aslan, 2009). Bu çalışmada ölçeğin cronbach alpha iç tutarlılık katsayısı $\alpha=, 90$ bulunmuştur.

\section{Verilerin Toplanmast}

Veriler Mersin Üniversitesi çalışanları ve öğrencileri özel eğitim kurumları öğrencileri ve Mersin Şehir Hastanesi çalışanlarından yüz yüze görüşerek toplanmıştır. Elde edilen veriler SPSS paket programına aktarılmıştır.

\section{Verilerin Analizi:}

Verilerin çözümlenmesinde SPSS 23.00 paket programı kullanılmıştır. Beliren Yetişkinlik döneminde olan bireyleri belirmek için yaşam görüşü ölçeği puanlarının ortalama ve standart sapması alınarak bir kesme noktası belirlenmiştir. Bu kesme noktası ve üzerinde puan alanlar 
beliren yetişkin olarak, altında puan alanlar beliren yetişkin olmayan olarak değerlendirilmiştir. Verilerin analizinde ANOVA ve $t$ Test kullanılmıştır. Ayrıca değişkenler arasındaki ilişkiyi belirlemek üzere korelasyon analizi yapılmıştır.

\section{BULGULAR}

Bu bölümde araştırma sonucunda elde edilen bulgular yer almaktadır.

Tablo 5. Beliren Yetişkinlik puanlarının Yaşa göre uygulanan tek yönlü varyans analizi (ANOVA) sonuçları

\begin{tabular}{lccccccccc}
\hline \multicolumn{1}{c}{ Puan } & Yaş & $\mathrm{n}$ & $\overline{\mathrm{X}}$ & $\mathrm{ss}$ & $\begin{array}{c}\text { Kareler } \\
\text { Toplamı }\end{array}$ & sd & $\begin{array}{c}\text { Kareler } \\
\text { Ortalamas1 }\end{array}$ & $\mathrm{F}$ & $\mathrm{P}$ \\
\hline Beliren yetişkinlik & 1 & 266 & 58,46 & 7,66 & 271,586 & 2 & 135,793 & 2,35 &, 108 \\
toplam puan & 2 & 298 & 58,38 & 8,02 & & 670 & & & \\
& 3 & 109 & 56,70 & 7,49 & & & & & \\
\hline Toplam & & 673 & 58,14 & 7,81 & & 672 & & & \\
\hline
\end{tabular}

Tablo 5'de görüldüğü gibi araştırma grubunun beliren yetişkinlik puanlarına uygulanan tek yönlü varyans analizi sonucunda, beliren yetişkinlik toplam puanlarında yaşa göre bir farklılaşma gözlenmemiştir $\mathrm{F}(2,670)=2,35, \mathrm{p}>0,05$. Bir başka ifadeyle, yaş arttıkça veya azaldıkça beliren yetişkinlik puanları farklılaşmamaktadır.

Tablo 6. Beliren Yetişkinlik toplam puanlarının cinsiyet faktörüne uygulanan göre t testi sonuçları

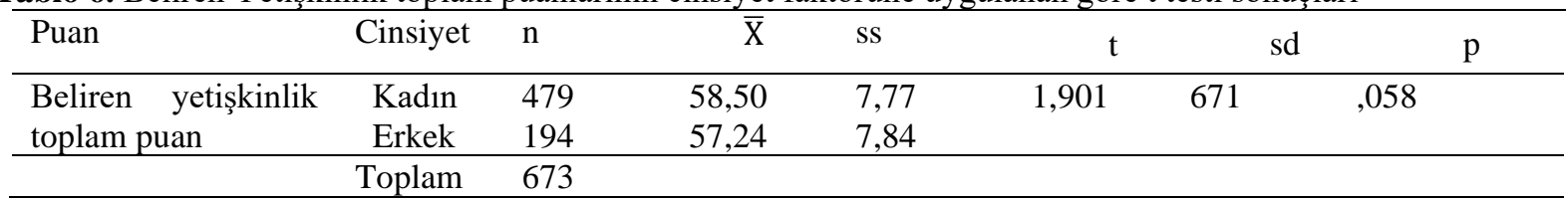

Tablo 6' da Bağımsız örneklem t testi erkek ve kadınların beliren yetişkinlik toplam puan farklarını ortaya koymak için kullanılmıştır. Analiz sonucunda, Kadın (58.70, SS=7,77 ve Erkek $(\mathrm{X}=57.24, \mathrm{SS}=7,84)$ grupları arasında istatistiksel olarak anlamlı bir fark bulunamamıştır $(\mathrm{t}(671)=1,901, \mathrm{p}>0,05)$.

Tablo 7. Beliren Yetişkinlik toplam puanlarının kaldığı yer faktörüne göre uygulanan tek yönlü varyans analizi (ANOVA) sonuçları

\begin{tabular}{lllcllllll}
\hline Puan & $\begin{array}{l}\text { Kaldığ } \\
\text { yer }\end{array}$ & $\mathrm{n}$ & $\overline{\mathrm{X}}$ & $\mathrm{ss}$ & $\begin{array}{l}\text { Kareler } \\
\text { toplamı }\end{array}$ & sd & $\begin{array}{l}\text { Kareler } \\
\text { ortalamas1 }\end{array}$ & $\mathrm{F}$ & $\mathrm{P}$ \\
\hline Beliren & 1 & 347 & 57,54 & 7,888 & 398,311 & 5 & 79,662 & 1,309 &, 258 \\
yetişkinlik & 2 & 25 & 57,80 & 7,000 & & 667 & & & \\
toplam & 3 & 66 & 58,58 & 6,973 & & & & & \\
puan & 4 & 27 & 58,15 & 9,339 & & & & \\
& 5 & 187 & 59,26 & 7,668 & & & & \\
& 6 & 21 & 57,14 & 8,696 & & & & \\
\hline Toplam & & 673 & 58,14 & 7,809 & & 672 & & \\
\hline
\end{tabular}

Tablo 7'de görüldüğü gibi araştırma grubunun beliren yetişkinlik toplam puanlarına uygulanan tek yönlü varyans analizi sonucunda, beliren yetişkinlik toplam puanlarında kaldığı yere göre bir farklılaşma gözlenmemiştir $\mathrm{F}(5,667)=1,309, \mathrm{p}>0,05$. Bir başka ifadeyle, kaldığ değiştikçe beliren yetişkinlik puanları farklılaşmamaktadır. 
Tablo 8. Beliren Yetişkinlik toplam puanlarının çalışma durumu faktörüne göre uygulanan tek yönlü varyans analizi (ANOVA) sonuçları

\begin{tabular}{llllllllll}
\hline Puan & $\begin{array}{l}\text { Çalışma } \\
\text { Durumu }\end{array}$ & $\mathrm{n}$ & $\overline{\mathrm{X}}$ & $\mathrm{ss}$ & $\begin{array}{l}\text { Kareler } \\
\text { toplamı }\end{array}$ & sd & $\begin{array}{l}\text { Kareler } \\
\text { ortalamas }\end{array}$ & $\mathrm{F}$ & $\mathrm{P}$ \\
\hline Beliren & 1 & 34 & 57,91 & 9,033 & 134,097 & 3 & 44,699 &, 732 &, 533 \\
yetişkinlik & 2 & 122 & 57,25 & 7,911 & & 669 & & & \\
toplam puan & 3 & 441 & 58,30 & 7,736 & & & & \\
& 4 & 76 & 158,75 & 7,524 & & & & \\
\hline Toplam & & 673 & 58,14 & 7,809 & & & & \\
\hline
\end{tabular}

Tablo 8'de görüldüğü gibi araştırma grubunun beliren yetişkinlik toplam puanlarına uygulanan tek yönlü varyans analizi sonucunda, beliren yetişkinlik toplam puanlarında çalışma durumuna göre bir farklılaşma gözlenmemiştir. $\mathrm{F}(3,669)=0,732, \mathrm{p}>0,05$ Bir başka ifadeyle, çalışma durumu değiştikçe beliren yetişkinlik puanları farklılaşmamaktadır.

Tablo 9. Deneyime Açıklık puanlarının Beliren Yetişkin olma ve olmama durumuna göre uygulanan t testi sonuçları

\begin{tabular}{llllllll}
\hline Puan & $\begin{array}{l}\text { Beliren yetişkin } \\
\text { olma durumu }\end{array}$ & $\mathrm{N}$ & $\overline{\mathrm{X}}$ & $\mathrm{ss}$ & $\mathrm{t}$ & $\mathrm{sd}$ & $\mathrm{p}$ \\
\hline Deneyime & 1 & 335 & 43,18 & 8,687 & 4,260 & 671 &, 000 \\
açılık & 2 & 338 & 40,34 & 8,602 & & & \\
\hline Toplam & 673 & & & & & \\
\hline
\end{tabular}

Tablo 9'da Bağımsız örneklem t testi beliren yetişkin olanların ve beliren yetişkin olmyanların beliren deneyime açıklık toplam puan farklarını ortaya koymak için kullanılmıştır. Analiz sonucunda, beliren yetişkin olanların $(X=43,18, S S=8,67)$ ve Beliren yetişkin olmayan $(\mathrm{X}=40.34, \quad \mathrm{SS}=8,602)$ grupları arasında istatistiksel olarak anlamlı bir fark bulunmuştur $(\mathrm{t}(671)=4,260, \mathrm{p}<0,05)$

Tablo 10. Yumuşak Başlılık puanlarının Beliren Yetişkin olma ve olmama durumuna göre uygulanan t testi sonuçları

\begin{tabular}{llllllll}
\hline Puan & $\begin{array}{l}\text { Beliren yetişkin } \\
\text { olma durumu }\end{array}$ & $\mathrm{N}$ & $\overline{\mathrm{X}}$ & $\mathrm{ss}$ & $\mathrm{t}$ & $\mathrm{sd}$ & $\mathrm{p}$ \\
\hline Yumuşak & 1 & 335 & 47,87 & 9,653 & 1,469 & 671 &, 142 \\
başlilık & 2 & 338 & 46,72 & 10,567 & & & \\
\hline Toplam & 673 & & & & & \\
\hline
\end{tabular}

Tablo 10'da. Bağımsız örneklem t testi beliren yetişkin olanların ve beliren yetişkin olmyanların beliren deneyime açıklık toplam puan farklarını ortaya koymak için kullanılmıştır. Analiz sonucunda, beliren yetişkin olanların $(X=47,87, \mathrm{SS}=9,653)$ ve Beliren yetişkin olmayan $(X=46.72, \mathrm{SS}=10,567)$ grupları arasında istatistiksel olarak anlamlı bir fark bulunamamıştır $(\mathrm{t}(671)=1,469, \mathrm{p}>0,05)$.

Tablo 11. Sorumluluk puanlarının Beliren Yetişkin olma ve olmama durumuna göre uygulanan $t$ testi sonuçları

\begin{tabular}{llcccccc}
\hline Puan & $\begin{array}{l}\text { Beliren yetişkin } \\
\text { olma durumu }\end{array}$ & $\mathrm{N}$ & $\overline{\mathrm{X}}$ & $\mathrm{ss}$ & $\mathrm{t}$ & $\mathrm{sd}$ & $\mathrm{p}$ \\
\hline sorumluluk & 1 & 335 & 36,43 & 8,524 &, 832 & 671 &, 406 \\
& 2 & 338 & 35,89 & 8,392 & & & \\
\hline Toplam & 673 & & & & \\
\hline
\end{tabular}

Tablo 11'de Bağımsız örneklem t testi beliren yetişkin olanların ve beliren yetişkin olmyanların beliren deneyime açıklık toplam puan farklarını ortaya koymak için kullanılmıştır. Analiz 
sonucunda, beliren yetişkin olanların $(\mathrm{X}=36,43, \mathrm{SS}=8,524)$ ve Beliren yetişkin olmayan $(\mathrm{X}=36,43 \mathrm{SS})$ grupları arasında istatistiksel olarak anlamlı bir fark bulunamamıştır $(\mathrm{t}(671)=$ $0,832, \mathrm{p}>0,05)$.

Tablo 12. Nevrotiklik puanlarının Beliren Yetişkin olma ve olmama durumuna göre uygulanan $t$ testi sonuçları

\begin{tabular}{llcccccc}
\hline Puan & $\begin{array}{l}\text { Beliren yetişkin } \\
\text { olma durumu }\end{array}$ & $\mathrm{N}$ & $\overline{\mathrm{X}}$ & $\mathrm{ss}$ & $\mathrm{t}$ & $\mathrm{sd}$ & $\mathrm{p}$ \\
\hline nevrotizm & 1 & 335 & 25,22 & 8,112 & 1,570 & 671 &, 117 \\
& 2 & 338 & 24,24 & 8,099 & & & \\
\hline Toplam & 673 & & & & & \\
\hline
\end{tabular}

Tablı 12' de Bağımsız örneklem t testi beliren yetişkin olanların ve beliren yetişkin olmyanların beliren deneyime açıklık toplam puan farklarını ortaya koymak için kullanılmıştır. Analiz sonucunda, beliren yetişkin olanların $(X=25,22, S S=8,112)$ ve Beliren yetişkin olmayan $(\mathrm{X}=24,24 \mathrm{SS}=8,099)$ grupları arasında istatistiksel olarak anlamlı bir fark bulunamamıştır $(\mathrm{t}(671)=1,570 \mathrm{p}>0,05)$.

\section{TARTIŞMA, SONUÇ VE ÖNERILER}

$\mathrm{Bu}$ araştırmada beliren yetişkinlik dönemini içerisinde olan ve beliren yetişkinlik dönemi içerisinde olmayan bireylerin kişilik özellikleri incelenmiştir. Ayrıca örneklem grubunda bireylerin beliren yetişkinlik durumu yaş, cinsiyet, çalışma durumu ve barındıkları yere göre incelenmiştir. Bu bölümde yukarıda bahsedilen araştırma bulguları daha önce yapılmış olan araştırmalar ve mevcut kuramlar ışığında tartışılmıştır.

Araştırma grubunun beliren yetişkinlik puanlarına uygulanan tek yönlü varyans analizi sonucunda, beliren yetişkinlik toplam puanlarında yaşa göre bir farklılaşma gözlenmemiştir. Bir başka ifadeyle, yaş arttıkça veya azaldıkça beliren yetişkinlik puanları farklılaşmamaktadır. Yapılan araştırmalarda (Arnett, 1998; Arnett, 2000; Arnett, 2004; Atak, 2005; Atak, 2011) beliren yetişkinlik için 18-26 yaş aralığı tespit edilmiş olsa da yaptığımız araştırmada bu yaş aralığının örneklemimiz kriteri olan 18-30 yaş aralığında farklılaşmaması beliren yetişkinlik döneminin 30 yaş hatta üzeri olabileceği düşünülmektedir. Türkiye İstatistik Kurumu'nun 2008-2017 yılları arasındaki verileri incelendiğinde yüksek öğrenime devam etme oranın $\operatorname{arttığı,işsiz~vatandaş~sayısının~arttığı~(TÜİK,~2019),~buna~bağlı~olarak~bireylerin~yetişkinlik~}$ sorumluluklarından uzak durmak istemeleri, gelişen teknolojiye bağlı marjinal yaşamların çok göz önünde olması ve buna özentinin artmış olması, lisans mezunu bireylerin artık kolay iş bulamamasına bağlı olarak bireylerin lisansüstü eğitime daha fazla yönelmelerinin etkili olabileceği düşünülmektedir.

Araştırma grubunun beliren yetişkinlik toplam puanlarına cinsiyete göre uygulanan $t$ testi sonucunda, beliren yetişkinlik toplam puanlarında cinsiyete göre bir farklılaşma gözlenmemiştir. Bu durum yapılan diğer araştırmalarla örtüşmemektedir (Arnett, 1998, Arnett, 2000; Arnett, 2004; Atak, 2005; Vural Yüzbaş, 2012; Ergin, 2015). Bu duruma günümüzde kadınların da erkekler kadar yetişkinlik sorumluluğunu üstlenmek zorunda olduklarını hissetmeleri ve günümüz koşullarında iş bulma ya da yeterli gelir elde etme sorunlarının neden olduğu düşünülmektedir.

Araştırma grubunun beliren yetişkinlik toplam puanlarına uygulanan tek yönlü varyans analizi sonucunda, beliren yetişkinlik toplam puanlarında kaldığı yere göre bir farklılaşma 
gözlenmemiştir. Bir başka ifadeyle, kaldığı yer değiştikçe beliren yetişkinlik puanları farklılaşmamaktadır. Bu bulgu yapılan diğer araştırmalarla örtüşmemektedir. Atak (2005), yaptığ 1 çalışmada anne-baba veya eşi ve çocuklarıyla yaşamayan bireylerin yaşayanlara göre beliren yetişkinlik puanlarının daha yüksek olduğunu bulmuştur. Araştırma sonuçlarına bakıldığında bulguların Atak'ın (2005) çalışmasıyla örtüşmediği görülmektedir. Kültürel değişim sosyal yaşamında değişmesine neden olmakta, sosyal yapıda meydana gelen değişim kültür ile paralel olarak değişmektedir. Toplumda benimsenmiş olan değer yargıları zaman içerisinde değişikliğe uğramakta, bu değerler çağın gereklerine göre değişmektedir (Süleymanov, 2009). Bu araştırmada ulaşılan bu sonucun değişen aile yapısı ile ilişkili olduğu düşünülmektedir.

Araştırma grubunun beliren yetişkinlik toplam puanlarına uygulanan tek yönlü varyans analizi sonucunda, beliren yetişkinlik toplam puanlarında çalışma durumuna göre bir farklılaşma gözlenmemiştir. Bir başka ifadeyle, çalışma durumu değiştikçe beliren yetişkinlik puanları farklılaşmamaktadır. Bu bulgu yapılan diğer araştırmalarla örtüşmemektedir (Atak, 2005, Ergin, 2015). Bu durumun nedeni olarak, örneklemimizdeki bireylerin bir işe girmiş olmayı ya da olmamayı bir yetişkinlik kriteri olarak algılamadıkları düşünülmektedir.

Araştırma grubunun nevrotizm puanlarına, beliren yetişkin olma ve olmama durumuna göre uygulanan $t$ testi sonucunda nevrotizm puanlarında bir farklılaşma gözlenmemiştir. Bu durum kuramsal açıdan beklenen bir sonuç değildir. Bireylerin beliren yetişkinlik dönemindeki keşifleri ve onların sevgideki ve işteki değişen seçimleri, beliren yetişkinliği istisnai derecede dolu ve yoğun bir yaşam dönemi haline getirmekte, aynı zamanda istisnai biçimde dengesiz kılmaktadır. Beliren yetişkinliğin istikrarsızlığının en iyi örneği, bir ikametten diğerine ne sıklıkta taşındıklarıdır. Bu durum beliren yetişkinliği dengesiz bir dönem yapar, ancak aynı zamanda beliren yetişkinlik yıllarında gerçekleşen keşifleri de yansıtır. Beliren yetişkinlik dönemindeki bireyler nadiren her yıl nerede yaşayacaklarını bilirler. Bu dengesizlik, beliren yetişkinlik döneminin ardından nevrotikliği, dolayısıyla yalnızlığı getirebilir (Atak, 2009).

Araştırma grubunun dişa dönüklük puanlarına, beliren yetişkin olma ve olmama durumuna göre uygulanan $t$ testi sonucunda dışa dönüklük puanlarında bir farklılaşma gözlenmiştir. Bir başka ifadeyle, beliren yetişkinlerin dışa dönüklük puanlarının ortalamalarının beliren yetişkin olmayanlardan istatistiksel olarak anlamlı düzeyde daha yüksek olduğu gözlenmiştir. Dışadönüklük boyutu girişkenlik, sosyal olma, düşüncelerinin arkasında olma, hakkını savunma, aktif ve konuşkan olma gibi özellikleri ifade etmektedir. Bu boyutun önemli bileşenleri hırs, tutku ve arkadaş canlısı olma özelliğidir (akt. Özer, 2013). Beliren yetişkinlik döneminin bir istikrarsızlık dönemi olduğu düşünüldüğünde elde edilen bu sonucun beliren yetişkinlik kuramı ile örtüşmediği düşünülmektedir. Sosyal bir ürün olan benlik, kültürel açıdan paylaşılan bir insan modelidir (Kağıtçıbaşı, 2012). Bu duruma Batı kültürü ile Türkiye arasındaki kültürel farklarında sebep olabileceği düşünülmektedir.

Kağıtçıbaşı (1988) dünyada görülen sosyal değişmenin modernleşme olarak tanımlandığını ve modernleşmenin hem sosyal yapıda kurumsal değişmeleri, hem de bireysel düzeyde tutum ve davranış değişimlerini içerdiğini belirtmektedir. Diğer yandan İçli (2001) küresel kitle kültürünün, kültürel üretimin modern araçlarının (görüntü, görsel ve grafik sanatlar, televizyon ve sinema, reklam gibi) egemenliğinde olduğunu ve batı merkezli olduğunu belirtmektedir. Ancak, bu kültürün farkl1lıkları özümsediğini, yerelliği ihmal edemediğini de belirtmektedir. $\mathrm{Bu}$ durumda küresel kültürel sürecin, çok uluslu merkezsiz bir karakter sergilediğini ifade etmektedir (İçli, 2001). İnsan davranışlarının oluşumunda kültürün önemli bir yeri vardır. Bu 
nedenle, batı toplumundaki bireylerin davranışlarının incelenmesi sonucu geliştirilen bir kuramın her zaman diğer topluların davranışlarını açıklaması beklenmez

Araştırma grubunun deneyime açıklık puanlarına, beliren yetişkin olma ve olmama durumuna göre uygulanan $t$ testi sonucunda deneyime açıklık puanlarında bir farklılaşma gözlenmiştir. Bir başka ifadeyle, beliren yetişkinlerin deneyime açıklı puanlarının ortalamalarının beliren yetişkin olmayanlardan istatistiksel olarak anlamlı düzeyde daha yüksek olduğu gözlenmiştir. Deneyime açıklık boyutu kişiler arası ilişkilerde açık olmaktan çok, yaşamsal deneyimlere açık olmak anlamına gelir. Bu boyutu oluşturan özellikler arasında güçlü bir hayal gücü, yeni görüşleri kabul etme isteği, çok yönlü düşünme ve zihinsel merak vardır (Burger, 2006). Beliren yetişkinlik döneminin bir en iyiyi arama, fursatları değerlendirme dönemi olduğu düşünüldügünde elde edilen bu sonucun beliren yetişkinlik kuramı ile uyumlu olduğu düşünülmektedir.

Araştırma grubunun yumuşak başl11ık puanlarına, beliren yetişkin olma ve olmama durumuna göre uygulanan $\mathrm{t}$ testi sonucunda yumuşak başl11ık puanlarında bir farklılaşma gözlenmemiştir. Yumuşak başlılık ile ilgili sınıflandırmalar, bireyin duygu, düşünce ve davranışlarında, şefkatten düşmanlığa kadar uzanan bir çizgi boyunca kişiler arası uyumun niteliğini değerlendirmek için kullanılır. Bu boyutta olan kişiler yumuşak kalpli, iyi huylu, güvenli, yardımsever, bağışlayıcı, saf ve dürüst olarak nitelendirilebilir (Costa \& McCrea, 1980). Beliren yetişkinlik döneminin bireyin kendine en çok odaklandığı dönem olduğu göz önüne alındığında bu sonucun beliren yetişkinlik kuramı açısında beklenen bir durum olduğu düşünülmektedir.

Araştırma grubunun sorumluluk puanlarına, beliren yetişkin olma ve olmama durumuna göre uygulanan $t$ testi sonucunda sorumluluk puanlarında bir farklılaşma gözlenmemiştir. Sorumluluk boyutu, bilinçlilik, başarılı yönelim, düzenlilik, etkili olma, planlılık, sorumluluk, mükemmeliyetçilik ve çok çalışkanlığı kapsar (Akt. Reisoğlu, 2014). Beliren yetişkinlik döneminin aslında bir bakıma bir takım sorumluluklardan kaçılan bir dönem olduğu, istikrarsız ve karasız bir dönem olduğu göz önüne alındığında elde edilen bu sonucun beliren yetişkinlik kuramı ile uyumlu olduğu düşünülmektedir.

Beliren yetişkinlik dönemi açısından yaş faktörünün önemli bir faktör olmadığı görülmüştür. Yapılan çalışmalarda 18-26 yaş aralığını beliren yetişkinlik için tespit edilmiş olsa da çalışma bulgularına göre bu aralığın18-30 yaş aralığı olabileceği düşünülmektedir. Çalışma bulguları cinsiyete göre farklılaşmadığı için beliren yetişkinlik döneminin hem kadınların hem de erkeklerin yaşadığı bir dönem olduğu gözlenmiştir. Çalışma durumunun beliren yetişkinlik için bir kriter olmadığ yetişkinlik kriteri olarak görmedikleri olduğu ön görülmektedir. Kişilik özellikleri bakımından araştırma bulgularına göre beliren yetişkinlik dönemindeki bireylerin dışa dönük kişilik özelliğine sahip olabilecekleri, bununla birlikte beliren yetişkinlik dönemindeki bireylerin deneyime açık kişilik özelliğine de sahip olabilecekleri ön görülmektedir.

Bu bölümde, bu araştırma bulgularına dayalı olarak araştırmacılara ve uygulamacılar önerilerde bulunulmuştur. 
Araştırmacılara yönelik öneriler:

1. Bu çalışma beliren yetişkinlik dönemindeki kişilik özelliklerini inceleyen bir araştırmadır. Araştırma bulgularında örneklem dahilindeki bireylerin beliren yetişkinlik yaşının araştırmadaki yaş sınırı olan 30'a kadar yükseldiğini gösterdiği düşünülmektedir. Yapılacak yeni araştırmalarda yaş sınırı yükseltilerek bu dönemin daha ileri yaşlarda yaşanıp yaşanmadığının incelenmesi beliren yetişkinlik dönemine yeni bir boyut kazandırılması açısından etkili olabilecektir.

2. $\mathrm{Bu}$ çalışmada beliren yetişkinlik dönemindeki bireylerin kişilik özellikleri incelenmiştir. Daha sonra yapılacak çalışmalarda beliren yetişkinlerin, mutluluk düzeyleri, yaşam doyumları, kişilerarası ilişkiler ve benzeri özellikleri incelenebilir.

3. Daha önceden yapılan çalışmalarda beliren yetişkinliğin 18-26 yaş aralığına özgü bir dönem olduğu ele alınmaktadır. Ancak, bu çalışmanın bulgularına göre bu aralığın 18-30 yaş aralığı olabileceği düşünülmektedir. Gelecekte yapılacak çalışmalarla böyle bir değişimin olup olmadığı ve böyle bir değişim var ise bu değişimin nedenleri incelenmelidir.

Uygulamac1lara yönelik öneriler:

1. Beliren yetişkinliğin 18-26 yaş aralığına özgü yeni bir gelişim dönemi olduğu ve kendine özgü örüntüler içerdiği ele alınmaktadır. Özellikle üniversitelerin psikolojik danışma ve rehberlik merkezlerinde çalışan psikolojik danışman ve psikologların, hizmet verdikleri bu grubun özelliklerini daha iyi anlamak açısından bu konuyla ilgili literatürü okuması gerekli olabilir.

2. Ruh sağlığı alanında çalışan psikolojik danışman, sosyal hizmet uzmanı, psikiyatrist ve psikologların, beliren yetişkinlik dönemini ayrı bir gelişim dönemi olarak ele alması ve mesleki etkinliklerinde bu dönemin özelliklerini dikkate alması faydalı olabilir.

3. Özellikle beliren yetişkinlik dönemindeki bireylere yönelik hizmet veren ruh sağlığı alanında çalışan meslek mensuplarının bu dönemdeki bireylerin yaşadığ sorunların ortadan kaldırılmasına yönelik yeni yaklaşımlar ve yöntemler geliştirmesi yararlı olabilir.

\section{KAYNAKÇA}

Arnett, J. J. (1998). Learning to stand alone: The contemporary American transition to adulthood in cultural and historical context. Human Development, 41(5-6), 295-315.

Arnett, J. J. (2000) Emerging adulthood: A theory of development from the late teens through the twenties. Am Psychol,55(5), 469-480.

Arnett, J. J. (2003). Conceptions of the transition to adulthood among emerging adults in American ethnic groups. New Directions In Child and Adolescent Development, 100, 63-75.

Arnett, J. J. (2004). Emerging adulthood: The winding road from the lateteens through the twenties. Oxford University Press.

Atak, H. (2005). Yeni bir yaşam döneminin türkiye'de incelenmesi. (Yayınlanmamış yüksek lisans tezi), Üniversitesi, Eğitim Bilimleri Enstitüsü.

Atak, H. (2009). Big five traits and loneliness among Turkish emerging adults. International Journal of Behavioral, Cognitive, Educational and Psychological Sciences, 1(2), 124-128. 
Atak, H., Tatlı, C., Çokamay, G., Büyükpabuşçu, H., \& Çok, F. (2016). Yetişkinliğe geçiş: Türkiye’ de demografik ölçütler bağlamında kuramsal bir gözden geçirme. Psikiyatride Güncel yaklaşımlar, 8(3) 204-227.

Bacanlı, H.; İlhan, T., \& Aslan, S. (2009). Beş faktör kuramına dayalı bir kişilik ölçeğinin geliştirilmesi: Sıfatlara dayalı kişilik testi (SDKT). Türk Eğitim Bilimleri Dergisi, 7(2), 261-279.

Bacanlı, H., \& Terzi, Ş. (2015). Yetişskinlik ve yaşlıllk gelişimi ve psikolojisi. Açılım Kitabevi.

Burger, J.M. (2006). Kişilik. (Çev. İ. D. Erguvan Sarığlu). Kaknüs yayınları.

Ergin, E. (2015). Beliren yetiş̧kinlik döneminde kimlik statüleri ve başa çıkma stratejileri ilişkisinin incelenmesi. (Yayınlanmamış Yüksek Lisans Tezi), Sosyal Bilimler Enstitüsü, Ufuk Üniversitesi.

İçli, G. (2001). Küreselleşme ve kültür. C.Ü. Sosyal Bilimler Dergisi, 25(2), 163-172

İnanç, B., \& Yerlikaya, E. (2016). Kişilik kuramları. Pagem Akademi yayınları.

Kağıtçıbaşı, Ç. (1988) Insan ve insanlar. Evrim Basım Yayım Dağıtım,

Kağıtçıbaşı, Ç. (2012). Benlik, aile ve insan gelişsimi. Koç Üniversitesi yayınları.

McCrea, R. R., \& Costa, P. T. (1999). A five- factor theory of personality. (Ed: L. A Pervin \& O.P. Jhon) In Handbook of Personality in Adulthood, Guilford Press.

McCrea, R. R., \& Costa, P. T. (2003). Personality in adulthood. Guilford Press.

Morsünbül, Ü., \& Çok, F. (2006) Kimlik gelişiminde yeni bir boyut: Seçeneklerin saplantılı araştırılması. Türk Psikolojik Danışma ve Rehberlik Dergisi, 5(40), 232-244.

Morsünbül, Ü., \& Tümen, B. (2008). Ergenlik döneminde kimlik ve bağlanma ilişkileri: Kimlik statüleri ve bağlanma stilleri üzerinden bir inceleme. Çocuk ve Gençlik Ruh Sağllğı Dergisi, 15(1), 25-31.

Morsünbül, Ü. (2013). Beliren yetişkinler mi beliren üniversiteli yetişkinler mi risk alma ve kimlik biçimlenmesi üzerine bir inceleme. Elemantary Education Online. 12(3), 873-885.

Seviniş, S., \& Bilgin, M. (2017). Yetişkinlerde sosyal ağ kullanımının beş faktör kişilik özellikleriyle ilişkisi. Journal of Human Sciences, 14(4), 3126-3157. https://doi.org/10.14687/jhs. v14i4.474

Süleymanov, A. (2009). Çağdaş türk toplumlarında aile ve evlilik ilişkileri. Aile ve Toplum Eğitim Kültür ve Araştırma Dergisi, 5 (17). 7-17.

Somer, O. (1998). Türkçe'de kişilik özelliğini tanımlayan sıfatların yapısı ve beş faktör modeli. Türk Psikoloji Dergisi, 13(42), 17-32. 


\section{EXTENDED ABSTRACT}

\section{Examination Of Personality Traits Of Individuals In Emerging Adulthood}

When development is examined as a whole, the period between adolescence and adulthood is very important for an individual to be qualified as an adult. In this case, the adulthood period begins with adolescence and ends when the individual sees himself as an adult. But it is not enough for the individual to feel like an adult alone. The individual's family and environment, and even from a wider perspective, the laws that are valid in the society and country in which he lives should see the individual as an adult. When individual and environmental processes are evaluated together; It is also important for individuals to evaluate the responsibilities of individuals, the privileges granted in society and the family, if they are adults or not. Emerging adulthood, like all developmental periods, has its own characteristics. Individuals in emerging adulthood are asked, "Who am I?" In many areas of their lives. They seek an answer to the question. In other words, they are discovering their own identities. In this period, identity discovery makes itself felt in three main areas. These are love, work, and worldview. Emerging adulthood is a period that is experienced very full and intensely, but in which there is a lot of variability in itself. This variability and instability are seen as a must-have feature of this period. Individuals in emerging adulthood know that they will draw many paths in the transition from adolescence to adulthood. Many have a path they choose for themselves. During this period, people were left on their own in many areas of life. They have to make most of their own decisions and run their lives. Emerging adults do not adapt their daily lives to the plans of their families like adolescents and children, nor do they continue their lives by assuming the responsibilities of their bosses, spouses, and children like adults. Emerging adults lead a life focused on themselves rather than all these responsibilities. This self-focus should not be perceived as selfish. Because during this period, self-focus is a healthy trait and is temporary. Individuals in this period are not seen as adults because they have not yet managed to stand on their own feet. However, they are not considered adolescents because they do not experience the addictions of adolescence. In other words, the responsibilities of adulthood and the limits of adolescence caused this period to be an intermediate period and the variability of this period. Because of these features, adults who appear are not adolescents, nor are they adults. They feel that they are in an interim transition period on their way to adulthood but not fully attained. Few things in an emerging adult's life are entirely certain and there are so many possibilities for the future. For this reason, this period is a period of great expectations and hopes. Individuals in this period make plans and dream about many issues. The hope and expectation levels of the individual to realize these plans are both positive and quite high. At this point, emerging adults look to the future and envision a good salary, a satisfying job, a lifelong marriage, and happierthan-average children. Individuals in this period continue to believe that even when they cannot get the job they dream of, make mistakes that will disrupt their life order, get divorced, or are in a serious struggle in their lives, they can ultimately control it. In short, this is a period in which hopes are quite high. Personality, on the other hand, is a pattern of traits that are consistent over time, continuous, predictable, idiosyncratic, and relatively situationindependent, that determine how an individual thinks, feels, and behaves in relation to himself and the outside world. Just because a personality is consistent or relatively permanent over time and regardless of the situation does not mean that it is fixed and does not change at all. Human beings are biopsychosocial and open to change. In this context, however, it is accepted that personality has an unchangeable side, it should also be taken into account that it is changeable. Man is the most complex creature in the universe, and psychologists do something very different from scientists when they study human behavior. Human beings try to recognize and 
understand their own structure, nature, and essence, not objects other than themselves. Since psychology is a young science and the research field is human, which is a complex structure, and it is not very suitable for objectively examining human beings, psychology has not reached definite information. For this reason, different approaches have emerged that try to explain the same phenomenon. Considering the difficulties of complex human behavior and self-study, it is inevitable that theories with different perspectives will emerge. The purpose of this research is to examine the personality traits of individuals in emerging adulthood.

When the emerging adulthood period was evaluated in terms of personality traits, a significant difference was found between emerging adulthood and extroverted personality and openness to experience. It has been observed that the age factor is not an important factor in terms of emerging adulthood. Although the 18-26 age range has been determined for emerging adulthood in the studies, it is thought that this range may be the 18-30 age range according to the study findings. Since the findings of the study did not differ according to gender, it was observed that the emerging adulthood period is a period in which both women and men live. It is predicted that employment status is not a criterion for emerging adulthood, and the reason for this is that individuals participating in the research do not see being employed as an adulthood criterion. According to the research findings in terms of personality traits, it is predicted that individuals in emerging adulthood may have extroverted personality traits, and individuals in emerging adulthood may also have openness to experience traits.

"International Journal of New Approaches in Social Studies - IJONASS" is licensed under a Creative Commons Attribution-NonCommercial-ShareAlike 4.0 International License. 